\title{
Research on Green Logistics System Based on Circular Economy
}

\author{
Liwen Zheng \\ Economics and Management Institute, Department of Management \\ Changchun University of Science and Technology \\ Changchun 130022, China \\ E-mail: zhangjuan5791@163.com \\ Juan Zhang \\ Economics and Management Institute, Department of Management \\ Changchun University of Science and Technology \\ Changchun 130022, China \\ E-mail: zhangjuan5791@163.com
}

\begin{abstract}
The development of cycle economic needs green of the area of material flow, green logistics is the main development trends of modern logistics. This paper explains the circular economy and the relationship between green logistics, using foreign concept of circular economy development of the green practice logistics, put forward a concrete implementation strategy of circular economy in China to develop green logistics from the view of government and business.
\end{abstract}

Keywords: Cycle economy, Green logistics system, Green logistics

\section{Cycle economy and green logistics}

Cycle economy is in accordance with the natural ecological system of material cycles and energy conversion law through the clean production technology and waste recovery technology to maximize the efficiency of resource use and minimization of waste discharge in order to achieve economic and environmental development. An important aspect of concept of circular economy is green material circulation, namely the development of green logistics.

Green logistics is the management activities to pursue customer satisfaction and social development goals, connecting the main body of green supply and demand, overcoming space and time obstacles to achieve efficient and rapid movement of goods and services. It inhibited the damage to environmental to achieve the purification of the logistics environment and the best use of logistics resources. Green logistics is a multi-level concept which includes both the green logistics business activities and social activities for green logistics management, standardize and control.

\subsection{Green logistics is the basic ties of circulatory system of green economy}

Green logistics form a resource conservation of resources, green products and green consumption .Green design and manufacturing is the premise to achieve green logistics and green consumption. Green logistics and other related distribution channels can react to promote green design and manufacturing and to meet and promote green consumption. Green logistics is the link between resources and products, products and consumer. Because of the existence of green logistics it was able to constitute a circular economy. Green logistics is the performance of cycle economic in the logistics industry, which status in the cycle economy can not be replaced and it is an important tool for the development of circular economy.

\subsection{Green logistics is an inherent requirement of the development of circular economy}

Material flow is the nature of all production and industrial operation. Material flow and energy flow is the basis for industrial systems. To achieve efficient use of materials and energy and a closed loop of material it is necessary to re-integration on the existing enterprise energy flow, material flow and information flow. It is the inherent requirement of circular economy and ecological industry to establish a good flow and recycling of green material between enterprises, and it is the essential characteristics of modern enterprises. In the performance of 
enterprises it is mainly the rationalization of production logistics and reasonable configuration management of supply chain logistics for the purchase and sale between enterprises, which is the important research of green logistics.

\subsection{Green logistics is an important way for the development of circular economy}

Logistics is the main artery of national economy. Both the exchange of material and energy between enterprises and society's economic activities can not be separated from the logistics. Green logistics is the logistics to further enhance its consideration of environmental and resources issues, which is a necessary requirement for sustainable development. If you only pay attention to the logistics without considering the green factor, then the economy will collapse at any moment of crisis. To further enhance the recycling economy, it is need to make further research and to develop green logistics, in particular it should be emphasized that the research on key issues of efficiency of logistics and reverse logistics, which plays an important role to the healthy development of circular economy. At the same time the healthy development of circular economy will promote the deepening of the theory of green logistics and further development of green logistics.

\subsection{Non-Green logistics limit the development of circular economy}

There is a one-way problem in non-green logistics, reflected in the only concern to the products from the resource to the consumption, not concerned about the waste product to be consumed after the logistics activities, only bring attention to the economic value of value-added logistics activities. Such activities may ignore the resource and environmental impact. The performance in logistics activities is such as the flow of processing, storage, transport, handling, packaging, distribution and other basic sectors, which inevitably run damage to the environment. For example, the transport of energy consumption and environmental pollution, the congestion distribution, storage, loading and unloading of waste production, distribution processing, packaging resource consumption and pollution.

To correct this negative effect, we need to change a perspective view of modern logistics activities, to consider the modern logistics in the place of ecological system, then, modern logistics is not only a subsystem of the economic system, but also "bridges" of economic and ecological systems that is to say to develop into green logistics in order to achieve economic development, logistics and the coupling cycle.

\section{Green logistics system based on circular economy in China}

\subsection{Government macroeconomic guide to green logistics system}

\subsubsection{Overall planning}

The Government should pay attention to green logistics system construction, planning green logistics development and implementation steps overall.

\subsubsection{Legal constraints}

The Government should continue to improve the logistics associated with the green laws and regulations, such as the "Environmental Protection Law", "Solid Waste Pollution Prevention Law," and noise pollution control regulations, and to build a green logistics system involving a set of all elements legal system.

\subsubsection{Policy control}

Government should guide green logistics enterprises with the use of various control methods, such as the increase in sewage charges, tax regulation, through credit, prices, subsidies and other ways to support the business development of green logistics.

\subsection{Concrete implementation on the green logistics system of enterprise}

\subsubsection{Use of green packaging}

First, use green packaging materials. Green packaging requirements in the selection of packaging materials environmental performance must be an important aspect of study. Paper is the most widely used green packaging materials. Biological gradable plastics are considered the most promising green packaging materials. Second, use recycling materials. If the packaging waste can be easily recovered, regenerated, not only help to reduce its impact on the environment, but also help to the use of recycled materials and to reduce waste disposal costs, which has obvious social and economic benefits. Thirdly, simplify packaging and appropriate packaging. The formation of excessive packaging waste is also cause unnecessary pollution. The new trend of simplify the packaging can significantly reduce packaging waste in line with the principle of reduction of circular economy. We should be vigorously promoted. 


\subsubsection{Green transport}

First, change the mode of transport, as far as possible to be consistent implementation of complex system of transport. The greatest impact on the environment is the means of transport, especially emissions, noise and traffic congestion caused by road transport. To change the mode of transport from road transport to railway transport or sea transport, this can reduce total traffic volume and ensure the transport process of optimization and efficiency as whole. Second, carry out joint distribution to improve resource utilization. Unified set of goods and uniform delivery can significantly reduce the flow of goods and effectively eliminate the staggered transport to ease traffic congestion conditions, which can improve the efficiency of urban freight transport, reduce no-load rate, and significantly reduce the level of business inventories. Third, develop third-party logistics. Third Party Logistics, which can help use and allocation of resources benefits in the broader context to avoid such issues as the amount of funds, used its own logistics, transportation low, and distribution links in red tape, increased pollution.

\subsubsection{Implementation of Green Storage}

The so-called green storage is reasonably required warehouse layout in order to reduce transport mileage and save transportation costs. If the warehouse layout is too dense, it would increase the number of transport, thereby increasing energy consumption and emissions of pollutants. If the layout is too loose, it will reduce the efficiency of freight transport and increase load rate. In addition, it also should take custody for different categories stored in different ways according to the performance of materials, characteristics. Various types of design and construction of storage facilities must meet the requirements of non-polluted environment, while strengthening maintenance of good humidity, corrosion, waterproofing, anti-change, leak-proof, anti-flying and so on.

\subsubsection{Green flow of processing}

One is to change consumers distributed processing to professional centralized processing to improve scale efficiency of resource use practices to reduce environmental pollution; Second, focus on scrap materials processing produced by consumer goods to reduce the spread pollution of consumers caused by the waste processing.

\subsubsection{Development of reverse logistics}

Reverse logistics are divided into recycling and waste logistics. For the repair of failed items, returns and turnover of packaging containers using renewable resources, companies can associate with other persons of supply chain to follow the circular economy of recycling and reuse principles through the construction of the Industrial Park and Green Supply chain approach to the establishment of recycling systems and to form logistics cycle systems. For waste, according to the actual need for the collection, classification, processing, packaging, handling, storage, and distribution to specialized treatment facility for processing.

\section{China's development strategy of logistics to promote circular economy}

\subsection{The Government should play a positive guidance and effective regulatory functions}

Government takes effectively functions which can create a good external environment for the development of green logistics, especially in the initial stage of green logistics. The Government should attach great importance to and vigorously support. The Government should control the activity occurred in sources of pollution such as sewage collection vehicle, a positive development of clean fuel vehicles, promote the railway, water transport, improve transport combinations, etc. From the limited of traffic to guide by the government in promoting enterprises choose the right transport way, such as the development of a common distribution, co-ordinate the establishment of a modern logistics center, ultimately limited by the logistics of traffic to improve efficiency; Through the development of road and rail interchange, the establishment of the city center ring road, development of on-street parking rules and traffic control systems to achieve modernization measures; the formulation of relevant laws, through the development of laws on resource exploitation, the use of new materials, emissions and waste recycling waste to regulate; development of transport vehicles such as the development of emission standards, noise standards, speed standards, safety standards, equipment specifications, provides equipment, use of fuel standards, handling tools to achieve standardization and standardization of packaging size; take fiscal, monetary instruments, give the necessary support and encouragement to the implementation of green logistics companies.

\subsection{The enterprise should build a kind of self-discipline-based logistics management system}

The basic subject of Green Logistics is business, so effective measures should be taken including all logistics companies to operate green. Environmental protection should permeate in the whole company functions and other functions and duties. 


\subsection{Establishing the concept of green consumption and to carry out green consumption}

Green consumption concepts and actions can stimulate green business operations of enterprises and promote the development of green logistics. Public green consumption should actively be promoted to choose green products (green products means the products and their packaging in the full life cycle are environmentally friendly and can be recycled after disposal and recycling); Recovery activities and renewable resource products should be supported.

\section{References}

Wang, Lan. (2005). Based on the circular economy of Green Supply Chain. China's urban economy, (11).

Wang, Shuyun \& Cao, Yongzhi. (2006). Review of Logistics Management Structure on transaction costs. Dynamic Economics, (4).

Wu, JianWen. (2005). On the Green Logistics. Logistics Technology, (6).

Zhang, Zeqiang \& Cheng, Wenming. (2003). Green logistics for eco-industry and circular economy. Crane, (9). 